\title{
Conflict of Interest Policies at Canadian Universities: Clarity and Content
}

This is a preprint of an article published in the Journal of Academic Ethics, 2008, 6(1):79-90 (URL: http://www.springerlink.com/content/yj1vm736661207g1/)

Bryn Williams-Jones, Programmes de bioéthique, Département de médecine sociale et préventive, Université de Montréal, Montreal, Canada

Chris MacDonald, Department of Philosophy, Saint Mary's University, Halifax, Canada

\section{Correspondence}

Bryn Williams-Jones

Programme de bioéthique

Université de Montréal, C.P. 6128, succ. Centre-ville

Montréal, Québec, Canada H3C 3J7

e-mail: bryn.williams-jones@umontreal.ca

\begin{abstract}
Abstract Discussions of conflict of interest (COI) in the university have tended to focus on financial interests in the context of medical research; much less attention has been given to COI in general or to the policies that seek to manage COI. Are university COI policies accessible and understandable? To whom are these policies addressed (faculty, staff, students)? Is COI clearly defined in these policies and are procedures laid out for avoiding or remedying such situations? To begin tackling these important ethical and governance questions, our study examines the COI policies at the Group of Thirteen (G13) leading Canadian research universities. Using automated readability analysis tools and an ethical content analysis, we begin the task of comparing the strengths and weaknesses of these documents, paying particular attention to their clarity, readability, and utility in explaining and managing $\mathrm{COI}$.
\end{abstract}

Keywords: Canada, conflict of interest, ethics, G13, policy, professors, readability, university

\section{Acknowledgements}

We thank the valuable research assistance of Elise Smith, Vincent Couture, Ashley Pringle and Aimee Smith who helped with background literature reviews, data collection and summary analyses. This study was supported by a grant from the Institute of Genetics of the Canadian Institutes of Health Research. 


\section{Introduction}

Conflict of interest (COI) can happen in a variety of professional and institutional contexts, and may manifest itself differently depending on the particular responsibilities of the professionals or institutions involved (Davis \& Stark 2001). It is thus increasingly common for organizations of all kinds-including corporations, universities, non-profit organizations, and government departments-to promulgate COI policies specific to their own work and context.

In the regulation of $\mathrm{COI}$, as in the regulation of other ethically complex problems, the promulgation of policy documents is at best a partial solution. It is widely recognized that such documents are never panaceas: even the best policies have gaps and are subject to being misunderstood, overridden or simply ignored. It is thus essential not only that members of organizations be educated about the existence and content of various policies, but also that leaders work hard to foster suitable ethical cultures within their organizations, such that ethics policies (including COI policies, amongst others) are acknowledged, talked about, understood and ultimately respected.

But to say that policies are never sufficient is not to say that they are unimportant. Such documents can educate, guide, and serve as a focal point for discussion. The individuals that inhabit organizations always have a range of interests and obligations, and those interests and obligations are bound, from time to time, to conflict. Sometimes, such conflicts can be avoided, if the individuals involved are suitably aware of the relevant worries and take precautionary measures. In other cases, such conflicts cannot be avoided, and those involved must do their best to mitigate any negative effects for the organization and its stakeholders. In either case, a clear and comprehensive policy document serves the dual purpose of educating and guiding the individuals involved.

The focus of the present paper is on the specific issues raised for academics and for the governance of $\mathrm{COI}$ in the university context. We begin with an exploration of the various ways in which $\mathrm{COI}$ can arise in university settings. Next, we review and assess the COI documents of Canada's "G13" universities. This very preliminary assessment comes in two parts. First, we describe and assess the results of an algorithm-based readability analysis in order to provide a rough appraisal of the extent to which the policies are written in clear and accessible language. Second, we conduct a content analysis in order to determine whether the various policies include the specific content that we argue is required in order for a COI policy to be ethically robust and practical. These preliminary studies cannot of course be conclusive. But the inventory they provide constitutes the beginning, at least, of an attempt to explore the adequacy of various institutions' $\mathrm{COI}$ documents in a consistent and rigorous way. Given that such documents are so often taken for granted, and their content and readability seen as less important than their bare existence, we see these preliminary steps as crucial.

\section{Conflicts of Interest in the University Context}

Universities are no longer simply places of higher learning where professors dedicate their time to teaching and research, activities traditionally considered the first and second missions of the university. Universities now have a third mission, to engage in industry collaborations, knowledge transfer and technology development (Bok 2003; Etzkowitz et al. 2000; Fisher and Atkinson-Grosjean 2002). Advocates of this third mission argue that greater industry involvement and collaboration in university research will provide, amongst other benefits, new funding streams to universities to make up for reduced public investment, stimulus for research collaborations, and translation of academic knowledge into marketable products that then stimulate technological and economic development. Proponents argue that collaborative research and knowledge transfer can contribute to broader social goods (e.g., economic 
development, access to new technologies) while also generating funds to support university research and infrastructure.

Opponents challenge this enthusiasm, arguing that university-industry relations, particularly relations involving patents and spin-off companies, can foster a climate of secrecy amongst researchers and university administrators and undermine the pursuit of basic or fundamental research. Moreover, opponents note that such relations rarely generate the promised revenue streams-most knowledge transferred to the private sector is still far upstream in the commercialization process-and point out that there are only a handful of US universities making significant revenue from university-industry relations (Agres 2003; Pressman 2003; Pressman et al. 2006). More worrisome, perhaps, is the concern that such relations create damaging conflicts of interest for researchers, administrators and even entire institutions (David 2000; Lewis et al. 2001; Schafer 2004). An over-emphasis on commercialization and industry involvement in the university, critics argue, directly threatens the fundamental norms of academic freedom, objectivity and the open sharing of knowledge that underpin the university's respected place in society (Royal Society 2003).

In this debate over the changing nature of higher education and the function of the university, concerns about $\mathrm{COI}$ have come to the forefront. A COI can be defined as "a situation in which a person has a private or personal interest sufficient to appear to influence the objective exercise of his or her official duties as, say, a public official, an employee, or a professional" (MacDonald et al. 2002, p. 68). Such conflicts may be characterized as real or potential (i.e., an actual conflict of interest or a situation that threatens to evolve into a conflict of interest), and/or apparent (i.e., perceived to be a conflict, whether real or potential). Even merely apparent COI can do significant damage to individual and institutional reputations, because even apparent $\mathrm{COI}$ maybe corrosive of trust. The primary concern is that $\mathrm{COI}$ in the university context threatens the objectivity, impartiality and credibility of judgments, whether in academic research or professional decision making, and leads to a subsequent loss of trust by staff, students and the broader public (Fersko and Merabet 2004).

Discussions in the ethics, bioscience and health policy literatures regarding $\mathrm{COI}$ in university contexts have tended to focus on professors and clinical researchers working in medical schools. This is understandable, given the significant interaction between medical researchers and the pharmaceutical and biotechnology industries. Particular attention has been given to the influence that receiving consultation or patient recruitment fees, or having shares in biotechnology or pharmaceutical companies supporting clinical trials, can have on medical judgment and patient safety in biomedical research (Cohen 2002; Schafer 2004). Concern has extended more generally to the effect of such relationships on publication of scientific research in peer-reviewed journals, and to the need for transparency and for declaration of competing interests in order to promote objectivity (Krimsky et al. 1999; Stein 2004). A cursory glance through the leading international bioscience and medical journals will find numerous discussions of the challenges posed by-and thus the need to regulate-individual and institutional conflicts of interest (Baird 2003; Fersko and Merabet 2004; Johns et al. 2003; Nathan and Weatherall 2002). The very real concern is that a range of institutional and commercial pressures are threatening the integrity of biomedical and clinical research. But COI in the university is diverse and extends well beyond the halls of biomedical or applied science departments, to include the humanities, law, engineering, and the social sciences.

In the university, COI tends to become a worry in situations in which professors or researchers have a financial or personal interest (e.g., in commercializing the results of their research) sufficient to appear to influence the objective exercise of their official duties, either as 
contributors to the shared body of knowledge or as educators. Yet $\mathrm{COI}$ is not limited to the research setting: teaching, administrative and support staff, and even students, may encounter situations in which they could be in real or apparent COI. For example, student teaching assistants may find themselves asked to grade their friends' exams; professors are required both to evaluate (i.e., grade) and to advocate for (e.g., to write letters of reference for) their graduate students; and many professors assign books they have written, and for which they receive royalties, as required course materials.

At the level of the institution, COI may arise when, for example, Heads of Department, Deans, members of Research Ethics Boards, or senior administrators (VP Research, President) feel pressured to support commercial or other agendas to the detriment of academic freedom or professional responsibilities (Johns et al. 2003; Resnik and Shamoo 2002). In its extreme form, implicit or explicit pressures on university administrators (e.g., to protect industry investments and interests) have lead to the suppression of negative research findings, the gagging of researchers, and neglect of university researchers faced with legal challenges from industry partners, as in the Olivieri and Healy cases at the University of Toronto (Angell 2004; Nathan and Weatherall 2002).

The most common method of mitigating the impact of a real, potential or apparent $\mathrm{COI}$ is to require the disclosure of interests. Once an individual's interests are transparent to the other parties involved in a decision making process, it then becomes possible for those others to balance or judge the statements and decisions made by that individual in light of their disclosed interests. Ethically, there is a parallel here with the notion of informed consent in human subjects research: disclosure gives those involved the opportunity to consent-or not-to the individual's continued participation in the decision-making process. However, it is generally acknowledged that many conflicts are sufficiently serious (e.g., in cases involving significant financial interests) that their influence cannot reliably be resolved by disclosure, audit or review. In such situations, often the only plausible solution is to remove the person from the situation in which their judgment is being trusted as independent and disinterested (Resnik 1998).

This threat to objectivity and public trust in professionals is considered sufficiently serious that many if not most professions have codes of ethics or codes of conduct that warn against COI. Whether the profession is formally licensed and self-regulating (e.g., medicine, nursing, engineering, accounting), or voluntary and unlicensed (e.g., university professors in general or specific academic disciplines), professionals are enjoined to aim for the highest standards of personal and professional integrity, to be aware of their significant social obligations and to behave in a manner worthy of public trust (Davis and Stark 2001). In the case of university professors, norms of objectivity, academic freedom, and collegiality may also be made explicit in university codes of conduct or ethics guidelines. However, very few ethics codes define 'conflict of interest' or provide guidance on how to avoid or mitigate such conflicts (Resnik 1998).

A widely used means of managing $\mathrm{COI}$ in the university context is through the promulgation of specific COI policy statements, regulations or guidelines. Yet as has become apparent through analyses of the implementation of informed consent documents in the clinical setting (Burgess 2001; Corrigan 2003; Dunne and Warren 1998), and of codes of ethics for professionals and businesses (Behrman 2001; Boo and Koh 2001; Stevens 2007), policy-based approaches to guiding or shaping ethical behaviour have serious practical limitations. Policies, whether dealing with research ethics or with $\mathrm{COI}$, are often written in a legalistic style that is hard for even well educated people to understand, and they are often geared towards mitigating institutional liability and so focus on listing 'do not' rules instead of providing positive guidance for 
addressing ethical challenges encountered. Further, these policies are often developed and implemented in a top-down manner with minimal grass-roots support or buy-in.

There have been a number of important surveys of the COI policies of major research universities in the United States (Boyd et al. 2004; Cho et al. 2000; Lipton et al. 2004), but attention has focused primarily on financial $\mathrm{COI}$ in the context of bioscience and universityindustry relations. There has been surprisingly little attention to COI in academia in general, or to those conflicts that involve interests other than financial interests. And it is not clear, based on those studies, whether university COI policies in general are accessible and understandable, or how they are perceived by members of the relevant university communities. To whom do these policies apply? Do they apply to professors and other researchers, or to all employees? Is COI clearly defined in these documents, and are procedures laid out for avoiding or remedying such situations? To begin addressing these important ethical and governance questions, we analysed the COI policies of thirteen major research universities in Canada.

\section{Methods: Analysing COI Policies in the G13 Universities}

Our study reviewed the COI guidelines or policy statements at the Group of Thirteen (or "G13") research universities in Canada. Similar to the American Ivy League or Big Ten, the Canadian G13 universities have the largest student enrolments, endowments, and research incomes among Canadian universities, and have national and international reputations for research and teaching (see Table 1). Most of these universities have medical and engineering schools, and undergraduate and graduate programs in most academic disciplines. Significantly for our purposes here, they also have Technology Transfer offices to facilitate university-industry collaborations, and professors and researchers who are actively involved in knowledge transfer and commercialization. Such being the case, we would reasonably expect these universities to have policies or guidelines that address COI.

Table 1: Canadian G13 Universities

\begin{tabular}{|l|l|l|l|l|l|}
\hline University & Location & $\begin{array}{l}\text { Founde } \\
\mathbf{d}\end{array}$ & $\begin{array}{l}\text { Full- } \\
\text { time } \\
\text { Student } \\
\mathbf{s}\end{array}$ & $\begin{array}{l}\text { Endowmen } \\
\text { t }\end{array}$ & $\begin{array}{l}\text { Research } \\
\text { income } \\
\text { annum) }\end{array}$ \\
\hline University of Alberta & Edmonton, Alberta & 1908 & 30,342 & $\$ 577$ million & $\$ 360$ million \\
\hline $\begin{array}{l}\text { University of British } \\
\text { Columbia }\end{array}$ & $\begin{array}{l}\text { Vancouver, British } \\
\text { Columbia }\end{array}$ & 1908 & 34,295 & $\$ 714$ million & $\$ 363$ million \\
\hline University of Calgary & Calgary, Alberta & 1966 & 24,241 & $\$ 293$ million & $\$ 251$ million \\
\hline Dalhousie University & Halifax, Nova Scotia & 1818 & 13,180 & $\$ 301$ million & $\$ 93$ million \\
\hline Université Laval & Quebec City, Quebec & 1663 & 26,760 & $\$ 112$ million & $\$ 280$ million \\
\hline McGill University & Montreal, Quebec & 1821 & 25,733 & $\$ 765$ million & $\$ 543$ million \\
\hline McMaster University & Hamilton, Ontario & 1887 & 19,633 & $\$ 340$ million & $\$ 246$ million \\
\hline Université de Montréal & Montreal, Quebec & 1878 & 41,349 & $\$ 105$ million & $\$ 384$ million \\
\hline University of Ottawa & Ottawa, Ontario & 1848 & 25,093 & $\$ 76$ million & $\$ 190$ million \\
\hline Queen's University & Kingston, Ontario & 1841 & 16,628 & $\$ 505$ million & $\$ 175$ million \\
\hline University of Toronto & Toronto, Ontario & 1827 & 59,148 & $\$ 1.5$ billion & $\$ 624$ million \\
\hline University of Waterloo & Waterloo, Ontario & 1957 & 22,604 & $\$ 97$ million & $\$ 110$ million \\
\hline $\begin{array}{l}\text { University of Western } \\
\text { Ontario }\end{array}$ & London, Ontario & 1878 & 28,560 & $\$ 199$ million & $\$ 191$ million \\
\hline
\end{tabular}

Source: 2004 data from a survey by CAUT (Canadian Association of University Teachers 2006).

Our initial supposition was that we would find one or a few key policy documents at each university that address $\mathrm{COI}$ for researchers and administrative staff. In fact, across the thirteen 
universities we examined, we found a wide variety of documents and diverse policy approaches for dealing with $\mathrm{COI}$. These varied from very general statements of principle, to brief discussions of $\mathrm{COI}$ in other documents (e.g., in guidelines on research ethics or on academic integrity), to focused COI policies for academic and/or non-academic staff, research assistants, and students. This diversity of documents reflects the often complex informational and regulatory context in which individual universities manage COI.

To focus our analysis, we restricted our review to those core policies that specifically target faculty members, or when those were unavailable, to policies that applied to university employees in general (and therefore to faculty members as well). There are of course other important categories of COI that are of interest at Canadian universities; consideration of those is beyond the scope of this paper. Each of the thirteen university websites was visited twice (in July 2006 and again in March 2007) and their key COI policies where identified and downloaded. These documents were then subjected to two types of analysis: (1) an automated readability analysis (Table 2 ), and (2) an ethical content

analysis (Table 3 ). Our goal was to examine, in a preliminary way, the ethical strengths and weaknesses of these documents, with particular attention to their clarity and readability, and their utility in explaining and managing COI.

\section{Readability analysis}

Readability is a crucial feature of any policy document. If a document cannot easily be read, interpreted, and understood, little else about it matters. The relative ease or difficulty of a written text can be evaluated quantitatively through the application of mathematical algorithms that analyse, amongst other elements, the length of sentences, number of syllables per word, average word length, etc., in order to produce a readability score. To evaluate the readability of the university COI policies, we used an open-access online readability testing service provided by Juicy Studio (2007) which combines three well known algorithms: the Gunning Fog Index, the Flesch Reading Ease Index, and Flesch-Kincaid Readability Test (Zakaluk and Samuels 1988). The Gunning Fog Index estimates how many years of schooling would be required to understand a text. Standard benchmarks in this regard include 8-10 years for popular novels, 10-14 years for newspapers and magazines, and 15-20 years for academic publications. The Flesch Reading Ease uses a 100 point scale, with 100 being the easiest to read; websites, for example, are recommended to aim for 60-70 points. The Flesch-Kincaid scale, like the Gunning Fog, ranks according to education level, but on a 12 point/grade spectrum with 12 being the most complex. It should be noted that for Gunning Fog and Flesch-Kincaid, a lower score means that a text is easier to read, while for Flesch Reading Ease the inverse is the case with a higher score denoting greater readability (Juicy Studio 2007).

Each university COI policy was copied into a Microsoft Word document to strip it of idiosyncratic formatting and ensure standardisation (e.g., to remove unnecessary line breaks); we then converted the policies into individual HTML pages (as required by the software) and subjected them to the online readability analysis. The readability scores for each university policy were compiled and given a rank from easiest to read (1) to most difficult to read (12) for each of the readability tests, and then were compiled to provide an aggregate score and overall ranking for each document (see Table 2). As the readability tests only work for English language texts, we were unable to evaluate the Université Laval's COI policy, which was only available in French, so policies were ranked form 1 to 12 instead of 1 to 13 . The Université de Montréal has an English translation of its policy which we included in the analysis, although only the French policy is considered official by the university. 
Table 2: Readability Analysis of University COI Statements

\begin{tabular}{|c|c|c|c|c|c|c|c|c|c|c|c|}
\hline University & $\begin{array}{c}\text { Total } \\
\text { words }\end{array}$ & $\begin{array}{c}\text { Average } \\
\text { words/ } \\
\text { Sentence }\end{array}$ & $\begin{array}{c}\text { \% of } \\
\text { words } \\
\text { with 3+ } \\
\text { syllables }\end{array}$ & $\begin{array}{c}\text { Gunning } \\
\text { Fog } \\
\text { Index }\end{array}$ & $\begin{array}{c}\text { Gunning } \\
\text { Rank }\end{array}$ & $\begin{array}{c}\text { Flesch } \\
\text { Reading } \\
\text { Ease }\end{array}$ & $\begin{array}{c}\text { Flesch } \\
\text { Rank }\end{array}$ & $\begin{array}{c}\text { Flesch- } \\
\text { Kincaid } \\
\text { Grade }\end{array}$ & $\begin{array}{c}\text { Flesch- } \\
\text { Kincaid } \\
\text { Rank }\end{array}$ & $\begin{array}{c}\text { Aggregate } \\
\text { Score }\end{array}$ & $\begin{array}{c}\text { Aggregate } \\
\text { Rank }\end{array}$ \\
\hline Alberta & 911 & 6.75 & $30.19 \%$ & 14.77 & $\mathbf{9}$ & 36.73 & $\mathbf{1 2}$ & 9.81 & $\mathbf{1 1}$ & 32 & $\mathbf{1 1}$ \\
\hline $\begin{array}{c}\text { British } \\
\text { Columbia }\end{array}$ & 3748 & 5.51 & $27.85 \%$ & 13.35 & $\mathbf{4}$ & 45.94 & $\mathbf{5}$ & 8.22 & $\mathbf{2}$ & 11 & $\mathbf{3}$ \\
\hline Calgary & 771 & 4.91 & $25.94 \%$ & 12.34 & $\mathbf{1}$ & 46.7 & $\mathbf{3}$ & 7.97 & $\mathbf{1}$ & 5 & $\mathbf{1}$ \\
\hline Dalhousie & 4197 & 7.34 & $28.12 \%$ & 14.18 & $\mathbf{8}$ & 42.48 & $\mathbf{7}$ & 9.16 & $\mathbf{7}$ & 22 & $\mathbf{7}$ \\
\hline Laval & NA & NA & NA & NA & NA & NA & NA & NA & NA & NA & NA \\
\hline McGill & 772 & 7.28 & $27.98 \%$ & 14.10 & $\mathbf{7}$ & 41.53 & $\mathbf{8}$ & 9.28 & $\mathbf{8}$ & 23 & $\mathbf{8}$ \\
\hline McMaster & 785 & 7.20 & $27.26 \%$ & 13.79 & $\mathbf{5}$ & 42.93 & $\mathbf{6}$ & 9.06 & $\mathbf{6}$ & 17 & $\mathbf{6}$ \\
\hline Montréal & 1015 & 7.36 & $25.75 \%$ & 13.23 & $\mathbf{2}$ & 48.92 & $\mathbf{2}$ & 8.26 & $\mathbf{3}$ & 7 & $\mathbf{2}$ \\
\hline Ottawa & 898 & 6.96 & $30.62 \%$ & 15.03 & $\mathbf{1 0}$ & 40.46 & $\mathbf{1 0}$ & 9.35 & $\mathbf{9}$ & 29 & $\mathbf{9}$ \\
\hline Queen's & 1912 & 8.17 & $29.45 \%$ & 15.05 & $\mathbf{1 1}$ & 40.89 & $\mathbf{9}$ & 9.59 & $\mathbf{1 0}$ & 30 & $\mathbf{1 0}$ \\
\hline Toronto & 2693 & 7.44 & $25.66 \%$ & 13.24 & $\mathbf{3}$ & 46.36 & $\mathbf{4}$ & 8.64 & $\mathbf{5}$ & 12 & $\mathbf{5}$ \\
\hline Waterloo & 1798 & 7.55 & $30.87 \%$ & 15.37 & $\mathbf{1 2}$ & 37.21 & $\mathbf{1 1}$ & 9.95 & $\mathbf{1 2}$ & 35 & $\mathbf{1 2}$ \\
\hline $\begin{array}{c}\text { Western } \\
\text { Ontario }\end{array}$ & 657 & 8.53 & $26.03 \%$ & 13.82 & $\mathbf{6}$ & 48.93 & $\mathbf{1}$ & 8.55 & $\mathbf{4}$ & 11 & $\mathbf{3}$ \\
\hline
\end{tabular}

Readability analysis performed using tools provided by Juicy Studio (Juicy Studio 2007). Gunning Fog measures years of schooling required; Flesch Reading Ease uses a 100 point scale, with 100 being the easiest to read; and Flesch-Kincaid grade measures required level of education (grades 1-12). For links to the universities COI policies, see (http://www.conflict-of-interest.net/canadianuniversities.htm).

An obvious limitation of these readability tests is that purely mathematical evaluation of a text is by no means definitive: these tests can only provide a rough measure. Moreover, when considering the readability of university $\mathrm{CO}$ policies, it must be acknowledged that the readerfor our purpose, university professors and staff-will typically be very well educated and should have little difficulty in comprehending even very complex texts. However, as will be discussed below, many of these policies may still be rather challenging for even educated individuals to understand, due to their often legalistic language, which is to some extent reflected in the ranking provided by the readability tests. Quantitative readability analyses have been used to good effect to study related documents, such as informed consent forms (Paasche-Orlow et al. 2003), patient information websites (Wilson et al. 2000), and academic textbooks (Gallagher and Thompson 1981). As an analytic tool, then, a readability test can be a useful means of evaluating the relative ease or complexity of a given text, and for our purposes, to compare and rank the conflict of interest policies of the G13 universities.

Upon examining Table 2, the first thing to note here is that there was relatively little variation, in terms of readability, among the various policies. On the Gunning Fog index, for example, the years of schooling required to understand the various policies ranged from 12.34 years (University of Calgary) to 15.37 years (University of Waterloo). Similarly, on the 100-point Flesch index, scores varied from a low of 36.73 (University of Alberta) to a high of 48.93 (University of Western Ontario). And on the Flesch-Kincaid scale, policies ranged from 7.97 (University of Calgary) to 9.95 (University of Waterloo). Thus the absolute differences between policies were relatively small. However, the aggregate rankings do reveal patterns. The University of Waterloo's policy, for example, scores at the bottom of the aggregate ranking because it ranks at or near the bottom on each of the three scales. That is, Waterloo's policy is consistently (though not tremendously) harder to read than, say, The University of Western Ontario's. 
It is also worth nothing that while the differences among policies were not large, none of the policies scored very well, and most of them have readability levels outside of the desirable range. Note for example that on the Gunning Fox Index, a score of 10-14 is recommended for newspapers and magazines. Yet Alberta, Dalhousie, McGill, Ottawa, Queen's, and Waterloo all had scores higher-i.e., worse-than that. Thus all of those policies are less readable than what is considered acceptable for magazines. It might be argued, of course, that that is a poor comparison, and that most of the persons reading these policies will be sufficiently highly educated that they ought not have any trouble understanding documents slightly more complicated than a magazine article. Such a response would be unfortunate, however. Instead of defending these documents, policy-makers ought simply to work harder at making them more readable. It is also worth noting that we are in no way arguing that $\mathrm{COI}$ documents should be maximally simplistic. Simplicity might well be achieved at the expense of clarity. But none of the documents examined were at risk of being accused of excessive simplicity: all were quite complex. It is worth asking, at least, whether the authors of these documents even considered (in any rigorous way) whether their documents were in fact readable.

\section{2) Content analysis}

Each university $\mathrm{COI}$ policy was read and analysed to see whether it included five major elements that we considered essential for a policy to be ethically robust and practical (See Table 3):

1. Date the policy was approved and/or revised: When the policy was produced or updated is an important marker of its relevance and ability to harmonize with more recent government policies and evolving 'best practices.'

2. Definition of COI: A clear explanation of what constitutes a COI is essential for a policy to be useful, given that $\mathrm{COI}$ may be complex in both its form and resolution.

3. Examples of COI: A logical corollary to a definition, examples will be critical to helping a reader understand and recognise $\mathrm{COI}$ in diverse settings.

4. Procedures to follow in the event of COI: Once a COI has been identified, there should be an explanation of the mechanisms by which it should be managed and resolved.

5. Further information on COI: Additional sources of information, such as examples, more detailed procedures, related ethics guidelines, etc., would help operationalize a COI policy. 
Table 3: Ethical Analysis of University COI Statements

\begin{tabular}{|c|c|c|c|c|c|c|}
\hline University & Scope & $\begin{array}{l}\text { Approved } \\
\text { \& Revised }\end{array}$ & Definition & Examples & Procedures & $\begin{array}{l}\text { Pointers to } \\
\text { Further Info }\end{array}$ \\
\hline Alberta & $\begin{array}{c}\text { All members of } \\
\text { university }\end{array}$ & 2003 & $\mathrm{Y}$ & $\mathrm{N}$ & $\mathrm{Y}$ & $\mathrm{Y}$ \\
\hline $\begin{array}{c}\text { British } \\
\text { Columbia }\end{array}$ & $\begin{array}{l}\text { Faculty, staff, } \\
\text { researchers, etc. }\end{array}$ & $\begin{array}{c}1992 \\
\operatorname{Rev} 2005\end{array}$ & $\mathrm{Y}$ & $\mathrm{Y}$ & $\mathrm{Y}$ & $\mathrm{N}$ \\
\hline Calgary & $\begin{array}{l}\text { Staff, students, } \\
\text { fellows, } \\
\text { researchers }\end{array}$ & $\begin{array}{c}1987 \\
\text { Rev } 2001\end{array}$ & $\mathrm{Y}$ & $\mathrm{Y}$ & $\mathrm{N}$ & $\mathrm{N}$ \\
\hline Dalhousie & All employees & 2002 & $\mathrm{Y}$ & $\mathrm{Y}$ & $\mathrm{Y}$ & $\mathrm{Y}$ \\
\hline Laval & $\begin{array}{l}\text { Researchers } \\
\text { (including } \\
\text { professors \& } \\
\text { students) }\end{array}$ & 1995 & $\bar{Y}$ & $\bar{Y}$ & $\bar{Y}$ & $\mathrm{~N}$ \\
\hline McGill & $\begin{array}{l}\text { All members of } \\
\text { university }\end{array}$ & 1997 & $\mathrm{Y}$ & $\mathrm{Y}$ & $\mathrm{Y}$ & $\mathrm{N}$ \\
\hline McMaster & Faculty & NA & $\bar{Y}$ & $\mathrm{~N}$ & $\bar{Y}$ & $\bar{Y}$ \\
\hline Montréal & $\begin{array}{l}\text { Teaching \& non- } \\
\text { teaching personnel }\end{array}$ & 1993 & $\mathrm{~N}$ & $\mathrm{Y}$ & $\mathrm{Y}$ & $\mathrm{N}$ \\
\hline Ottawa & $\begin{array}{l}\text { All members of } \\
\text { university }\end{array}$ & $\operatorname{Rev} 1995$ & $\mathrm{~N}$ & $\bar{Y}$ & $\mathrm{Y}$ & $\mathrm{Y}$ \\
\hline Queen's & $\begin{array}{l}\text { Staff not in Faculty } \\
\text { Association }\end{array}$ & $\begin{array}{c}1995 \\
\operatorname{Rev} 2001\end{array}$ & $\mathrm{Y}$ & $\mathrm{Y}$ & $\mathrm{Y}$ & $\mathrm{N}$ \\
\hline Toronto & Academic staff & 1994 & $\mathrm{Y}$ & $\mathrm{Y}$ & $\mathrm{N}$ & $\mathrm{N}$ \\
\hline Waterloo & $\begin{array}{l}\text { All members of } \\
\text { university }\end{array}$ & 1991 & $\mathrm{Y}$ & $\mathrm{Y}$ & $\mathrm{Y}$ & $\mathrm{Y}$ \\
\hline $\begin{array}{c}\text { Western } \\
\text { Ontario }\end{array}$ & Faculty and staff & 2000 & $\mathrm{Y}$ & $\mathrm{Y}$ & $\mathrm{Y}$ & $\mathrm{N}$ \\
\hline
\end{tabular}

One of the premises of our analysis here is the idea that COI documents ought to be more than simply policies whose very existence is hoped to mitigate legal liability. Mitigation of liability is of course an important goal. But more important is the provision of clear and comprehensive guidance to the university community, in order to make sure that members of that community, and the university as whole, are able to meet their ethical obligations.

An ideal COI policy would be current, would define and give examples of COI, would clearly explain how to avoid $\mathrm{COI}$ where possible and how to mitigate dangers where avoiding $\mathrm{CO}$ proves impossible. Further, an ideal policy should recognize its own limitations, and hence provide readers with guidance regarding where to look for additional information. The ideal policy would be relatively comprehensive yet still reasonably concise, would be written in an accessible and not overly legalistic style, and would focus on educating readers and on encouraging ethical behaviour.

How do the 13 policies we examined stack up to this ideal standard? Most policies (12 out of 13) did provide a definition of COI, most gave examples (11 out of 13) and most explained procedures for dealing with $\mathrm{COI}$ (12 out of 13). Far fewer provided links to additional information (just 5 out of 13). Most of the policies were legalistic in style and language, and most focused on listing prohibitions as well as procedures for mitigating institutional liability. Only 2 of the 13 policies, those of Dalhousie and Waterloo, featured all 5 of our desiderata. We suggest that, strictly in terms of content, the four best policies were those from Dalhousie, Waterloo, Queen's, and British Columbia. Generally, though, we found these 13 documents to be lacking in appropriate content. Most of them provided definitions, but those definitions were not always clear (a full analysis of the shortcomings of these definitions is beyond the scope of this paper.) 
Some policies mixed examples into their definitions, but many of them provided no examples at all. Most documents indicated the existence of procedures for dealing with COI, but often those procedures were not well explained, and often no indication was given as to where to find more information about those procedures. In one case (McMaster), there were diverse but disconnected sources of information on COI but no central policy-the most detailed information was found in the faculty handbook section on research ethics (which is what we analysed). Interestingly, McMaster did have a coherent COI policy for non-academic staff. Finally, very few of the policies provided readers with links or other pointers to further information about COI, so those policies miss out on a crucial opportunity to work as educational documents, rather than (solely) as guides for short-term decision-making.

It is interesting to note that there is no apparent correlation between our readability and content analyses. The best policies in terms of readability (University of Western Ontario and University of Calgary) were both very short: each features only a rudimentary definition of $\mathrm{COI}$, and each is thin on examples and details. Conversely, the most comprehensive policies in terms of content-namely Dalhousie and Waterloo-ranked $7^{\text {th }}$ and $12^{\text {th }}$ respectively in the readability analyses. This is part of a larger pattern: legalistic texts had better readability rankings, likely because they feature shorter sentences (e.g., bullet-pointed items) and shorter overall length. This might reflect a weakness in the automated analysis: though legalistic texts might well tend to have shorter sentences, and although shorter sentences tend to be very readable, jargonladen legalistic documents are notoriously difficult for most people to read. More generally, however, the disconnect found between readability and comprehensiveness reminds us that writing an effective policy document is a complex optimization problem, requiring careful attention to detail and, ideally, an iterative process of drafting, testing, and re-drafting.

\section{Conclusion}

It seems quite likely that many problems related to $\mathrm{COI}$ result from individuals having a poor understanding of the relevant institutional guidelines and procedures and a belief that they can manage COI on their own (Lipton et al. 2004). While the questions of personal bias and individual integrity - which so often dominate discussions of COI - are important, addressing them can only be part of the solution. There is, we suggest, a need to emphasize awareness of the situational aspects of COI: that is, COI policies should help members of the academic community (faculty, administrators, non-teaching staff, students) understand the specific contexts in which COI occur (e.g., various academic departments, research or teaching settings); discern the different types and severity of COI (e.g., financial, prestige, or familial relations), and then choose the appropriate responses (i.e., disclosure, withdrawal or avoidance). As MacDonald, McDonald \& Norman note, there is nothing necessarily blameworthy about finding oneself in a COI; sometimes institutional arrangements make COI likely, even inevitable (MacDonald et al. 2002). What matters, ethically, is that individuals and institutions deal appropriately with $\mathrm{COI}$ when it arises. Good COI policies are an obvious first step in that direction. 


\section{References}

Agres, T. 2003. "The fruits of university research" The Scientist 17(14): 55-56.

Angell, M. 2004. The Truth About the Drug Companies: How They Deceive Us and What to Do About It. (New York: Random House).

Baird, P.A. 2003. "Getting it right: industry sponsorship and medical research" Canadian Medical Association Journal 168(10): 1267-1269.

Behrman, J.N. 2001. "Adequacy of international codes of behavior" Journal of Business Ethics 31(1): 51-64.

Bok, D. 2003. Universities in the Marketplace: The Commercialization of Higher Education. (Princeton: Princeton University Press).

Boo, E.H.Y. \& Koh, H.C. 2001. "The influence of organizational and code-supporting variables on the effectiveness of a code of ethics" Teaching Business Ethics 5(4): 357-373.

Boyd, E.A., Lipton, S. \& Bero, L.A. 2004. "Implementation of financial disclosure policies to manage conflicts of interest" Health Affairs 23(2): 206-214.

Burgess, M.M. 2001. "Beyond consent: Ethical and social issues in genetic testing" Nature Reviews: Genetics 2(2): 147-152.

Canadian Association of University Teachers. 2006. CAUT Almanac of Post-Secondary Education 2006 (Ottawa: Canadian Association of University Teachers), (http://www.caut.ca/en/publications/almanac/default.asp) [accessed: February 28 2007].

Cho, M.K., Shohara, R., Schissel, A. \& Rennie, D. 2000. "Policies on faculty conflicts of interest at US universities", In Journal of the American Medical Association: Am Med Assoc.

Cohen, J.J. 2002. "Managing financial conflicts of interest in clinical research" Science and Engineering Ethics 8(3): 401-406.

Corrigan, O.P. 2003. "Empty ethics: The problem with informed consent" Sociology of Health and IIIness 25(7): 768-792.

David, P.A. 2000. "A tragedy of the public knowledge 'commons'? Global science, intellectual property and the digital technology boomerang" Electronic Journal of Intellectual Property Rights WP 04: 1-34, (http://www.oiprc.ox.ac.uk/EJWP0400.pdf).

Davis, M. \& Stark, A., eds. 2001. Conflict of Interest in the Professions. (New York, NY: Oxford University Press).

Dunne, C. \& Warren, C. 1998. "Lethal autonomy: The malfunction of the informed consent mechanism within the context of prenatal diagnosis of genetic variants" Issues in Law \& Medicine 14(2): 165-202.

Etzkowitz, H., Webster, A., Gebhardt, C. \& Cantisano Terra, B.R. 2000. "The future of the university and the university of the future: Evolution of ivory tower to entrepreneurial paradigm" Research Policy 29: 313-330. 
Fersko, R.S. \& Merabet, H. 2004. "Sponsored research and the public's right to know" Drug Development Research 63(3): 103-111.

Fisher, D. \& Atkinson-Grosjean, J. 2002. "Brokers on the boundary: Academy-industry liaison in Canadian universities" Higher Education 44(3-4): 449-467.

Gallagher, D.J. \& Thompson, G.R. 1981. "A Readability Analysis of Selected Introductory Economics Textbooks" The Journal of Economic Education 12(2): 60-63.

Johns, M.M.E., Barnes, M. \& Florencio, P.S. 2003. "Restoring balance to industry-academia relationships in an era of institutional financial conflicts of interest: Promoting research while maintaining trust" Journal of the American Medical Association 289(6): 741-746.

Juicy Studio. 2007 "Readability Test" (http://juicystudio.com/services/readability.php) [accessed: May 5].

Krimsky, S., Rothenberg, L.S., Stott, P. \& Kyle, G. 1999. "Scientific journals and their author's financial interests: A pilot study" In The Commercialization of Genetics Research: Ethical, Legal, and Policy Issues, edited by T.A. Caulfield \& B. Williams-Jones. (New York, NY: Kluwer Academic / Plenum Publishers), p. 101-110.

Lewis, S., Baird, P.A., Evans, R.G., et al. 2001. "Dancing with the porcupine: Rules for governing the university-industry relationship [Commentary]" Canadian Medical Association Journal 165(6): 783-785.

Lipton, S., Boyd, E.A. \& Bero, L.A. 2004. "Conflicts of interest in academic research: Policies, processes, and attitudes" Accountability in Research: Policies and Quality Assurance 11(2): 83-102.

MacDonald, C., McDonald, M. \& Norman, W. 2002. "Charitable conflicts of interest" Journal of Business Ethics 39(1-2): 67-74.

Nathan, D.G. \& Weatherall, D.J. 2002. "Academic freedom in clinical research" New England Journal of Medicine 347(17): 1368-1371.

Paasche-Orlow, M.K., Taylor, H.A. \& Brancati, F.L. 2003. "Readability Standards for InformedConsent Forms as Compared with Actual Readability" New England Journal of Medicine 348(8): 721-726.

Pressman, L. 2003. AUTM Licensing Survey: FY 2001 (Northbrook, IL: AUTM).

Pressman, L., Burgess, R., Cook-Deegan, R.M., et al. 2006. "The licensing of DNA patents by US academic institutions: An empirical survey" Nature Biotechnology 24(1): 31-39.

Resnik, D.B. 1998. "Conflicts of interest in science" Perspectives on Science 6(4): 381-408.

Resnik, D.B. \& Shamoo, A.E. 2002. "Conflict of interest and the university" Accountability in Research 9(1): 45-64. 
Royal Society. 2003. Keeping Science Open: The Effects of Intellectual Property Policy on the Conduct of Science (London: Royal Society,),

(http://www.royalsoc.ac.uk/document.asp?tip=0\&id=1374).

Schafer, A. 2004. "Biomedical conflicts of interest: A defence of the sequestration thesis-learning from the cases of Nancy Olivieri and David Healy" Journal of Medical Ethics 30(1): 8-24

Stein, C.M. 2004. "Publishing work sponsored by the tobacco industry" Clinical Pharmacology \& Therapeutics 76(6): 517-518.

Stevens, B. 2007. "Corporate ethical codes: Effective instruments for influencing behavior" Journal of Business Ethics Advance online publication: 10.1007/s10551-007-9370-z.

Wilson, F.L., Baker, L.M., Brown-Syed, C. \& Gollop, C. 2000. "An analysis of the readability and cultural sensitivity of information on the National Cancer Institute's Web site: CancerNet" Oncology Nursing Forum 27(9): 1403-9.

Zakaluk, B.L. \& Samuels, S.J. 1988. Readability: It's Past, Present, and Future. (Newark, Del: International Reading Association). 